\title{
Pengaruh model Project Based Learning terhadap keterampilan berpikir kreatif dalam pembelajaran fisika terapan
}

\author{
${ }^{1 *}$ Chairatul Umamah, ${ }^{2}$ Herman Jufri Andi \\ ${ }^{1}$ Prodi Pendidikan Fisika, Universitas Islam Madura, JL. Pondok Peantren Miftahul Ulum Bettet 69317, \\ Indonesia \\ e-mail: chairatul.physics@gmail.com
}

\begin{abstract}
Abstrak
Penelitian ini bertujuan untuk mengetahui bagaimana pengaruh penggunaan model project based learning $(\mathrm{PjBL})$ terhadap keterampilan berpikir kreatif dalam pembelajaran fisika terapan. Penelitian ini dilakukan di Prodi Pendidikan Fisika Universitas Islam Madura. Metode penelitian yang digunakan adalah Quasi Experimental Design. Desain yang digunakan yaitu Nonequivalent Control Group Design. Sampel yang digunakan terdiri dari dua kelas, kelas A sebagai kelas kontrol dan kelas $B$ sebagai kelas eksperimen dengan jumlah masing-masing kelas 22 orang. parameter penelitian yang diukur meliputi keterampilan berpikir kreatif mahasiswa yang meliputi aspek: berpikir lancar, berpikir luwes, berpikir orisinil dan berpikir elaborasi. Teknik analisis data menggunakan deskriptif kuantitatif dengan bantuan program SPSS 22.0 For windows. Hasil analisis data dengan menggunakan uji-T (hipotesis). Dari hasil analisis data dan pembahasan dapat disimpulkan bahwa terdapat pengaruh yang signifikan dari penggunaan model Project Based Learning ( $\mathrm{PjBL}$ ) terhadap keterampilan berfikir kritis mahasiswa pada matakuliah Fisika Terapan. Hasil ini dapat ditunjukkan bahwa kelas Eksperimen memiliki pencapaian keterampilan berpikir kreatif yang secara signifikan lebih tinggi dari kelas kontrol.
\end{abstract}

Kata Kunci: Project Based Learning; keterampilan berpikir kreatif; fisika terapan.

\section{Effect of Project Based Learning models on creative thinking skills in learning of applied physics}

\begin{abstract}
This study aims to determine how the influence of the use of project based learning (PjBL) models on creative thinking skills in applied physics learning. This research was conducted in the Physics Education Study Program of Madura Islamic University. The research method used is Quasi Experimental Design. The design used is the Nonequivalent Control Group Design. sample used in this research consists of two classes. They are class $A$ as control class and class B as experimental class with the number of each class is 22 students. The measured research parameters include students' creative thinking skills is consist of four aspects, they are:thinking smoothly, thinking flexibly, thinking originally and thinking elaboration. Data analysis techniques using quantitative descriptive with SPSS 22.0 for windows. The results of data analysis using the T-test (hypothesis). From the results of data analysis and discussion it can be concluded that there is a significant effect of using Project Based Learning (PjBL) models on students' critical thinking skills in Applied Physics courses. It can be shown that the Experimental class has the achievement of creative thinking skills that are significantly higher than the control class.
\end{abstract}

Keywords: Project Based Learning; creative thinking skills; applied physics

How to Cite: Umamah, C., \& Andi, H. (2019). Pengaruh model Project Based Learning terhadap keterampilan berpikir kreatif dalam pembelajaran fisika terapan. Jurnal Pendidikan Fisika dan Keilmuan (JPFK), 5(1), 7-14. doi:http://dx.doi.org/10.25273/jpfk.v5i1.3033 


\section{PENDAHULUAN}

Pendidikan nasional diarahkan dengan tujuan untuk mengembangkan keterampilan peserta didik dalam mencerdaskan kehidupan bangsa dan bertujuan untuk mengembangkan potensi peserta didik agar menjadi manusia yang beriman dan bertakwa kepada Tuhan Yang Maha Esa, berakhlak mulia, sehat, berilmu, cakap, kreatif, mandiri, dan menjadi warga negara yang demokratis serta bertanggung jawab. Dalam UU No 20 pasal 03 tahun 2003 tentang sistem pendidikan nasional dijelaskan bahwa salah satu tujuan Pendidikan nasional adalah terciptanya peserta didik yang kreatif. Pada era globalisasi, keterampilan berpikir kreatif menjadi bekal Dalam menyongsong revolusi industri 4.0 (Triani, Zulkarnain, \& Utami, 2015).

Mata kuliah Fisika terapan sebagai bagian dari sains dalam menghadapi revolusi industri di era globalisasi membekali peserta didik dengan kompetensi teori dan konsep fisika agar menunjang terciptanya keterampilan berpikir kreatif. Fisika terapan pada hakikatnya tidak hanya mengajarkan pengetahuan (kognitif) saja, tetapi juga melatihkan sikap dan keterampilan yang dibutuhkan mahasiswa dalam mengatasi berbagai masalah yang ada dan belajar bagaimana berinteraksi dengan orang lain. Jika selama ini fisika dianggap sebagai ilmu tentang rumus dan soalsoal, maka sudah saatnya bagi mahasiswa untuk menjadi lebih akrab dengan fisika. Untuk menghadirkan pembelajaran yang menyenangkan bagi mahasiswa maka proses pembelajaran di dalam kelas harus diselenggarakan dengan baik dan bermutu (Jagantara, Adnyana, \& Widiyanti, 2014).

Realita di lapangan, beberapa permasalahan yang terjadi adalah mahasiswa masih kesulitan dalam menyelesaikan soal pada ranah kognitif C4 (menganalisis), C5 (mengevaluasi) dan C6 (mencipta). Berdasarkan analisis dari hasil wawancara, bahwa permasalahan yang terjadi disebabkan karena rendahnya keterampilan berpikir kreatif mahasiswa, yang berdampak pada kesulitan mahasiswa dalam menyelesaikan soal pada ranah kognitif yaitu menganalisis, mengevaluasi dan mencipta. kurangnya minat belajar dan rasa ingin tahu mahasiswa dalam belajar, mahasiswa takut dan malu dalam mengeluarkan dan memberikan pendapat. Akibatnya keterampilan berpikir kreatif mahasiswa menjadi rendah yang secara langsung juga berdampak pada hasil belajar. Selain itu, dalam proses pembelajaran mahasiswa kurang dilatih menggunakan keterampilan berpikir dengan cara sendiri dan mereka terbiasa dengan sistem pembelajaran seperti mendengarkan penjelasan dosen dan mengerjakan latihan soal. Sehingga pembelajaran masih berpusat pada dosen dan mahasiswa kurang dilatih untuk mengembangkan keterampilan berpikir kreatif yang dimiliki (Purwasih, Ambarita, \& Muncarno, 2017).

Menumbuhkan keterampilan berpikir kreatif sangat penting dalam dunia pendidikan, karena dengan adanya keterampilan berpikir kreatif siswa akan mampu mengambil keputusan yang tepat dalam suatu permasalahan. lima indikator berpikir kreatif, yaitu: 1. Kepekaan (problem sensitivity), adalah keterampilan mendeteksi, mengenali, dan memahami serta menanggapi suatu pernyataan, situasi, atau masalah; 2. Kelancaran (fluency), adalah keterampilan untuk menghasilkan banyak gagasan; 3 . Keluwesan (flexibility), adalah keterampilan untuk mengemukakan bermacammacam pemecahan atau pendekatan terhadap masalah; 4. keaslian (originality), adalah keterampilan untuk mencetuskan gagsan dengan cara-cara yang asli, tidak klise, dan jarang diberikan kebanyakan orang; 5. Elaborasi (elaboration), adalah keterampilan menambah suatu situasi atau masalah sehingga menjadi lengkap, dan merincinya secara 
detail, yang didalamnya terdapat berupa tabel, grafik, gambar, model dan kata-kata (Yunianta, Rusilowati, \& Rochmad, 2012).

Untuk itu diperlukan model pembelajaran yang dapat menumbuhkan keterampilan berpikir kreatif mahasiswa. Solusi yang dilakukan untuk meningkatkan kualitas proses pembelajaran mata kuliah fisika terapan adalah memperbaiki proses pembelajaran dengan menggunakan model pembelajaran yang sesuai yang dapat menumbuhkan aspek kognitif dan psikomotoris mahasiswa (Waluyo, 2014). Model pembelajaran yang sesuai untuk menumbuhkan kemamapuan berpikir kreatif mahasiswa pada mata kuliah fisika terapan adalah model Project Based Learning (PjBL). PjBL merupakan sebuah model yang mengatur pembelajaran melalui proyek-proyek tertentu. Proyek adalah tugas yang diberikan berdasarkan pertanyaan atau masalah yang menantang, melibatkan mahasiswa dalam perancangan, pemecahan masalah, memberikan keputusan, atau menyelidiki aktivitas, memberikan hak secara otonomi selama periode waktu untuk mengumpulkan dan mengintegrasikan pengetahuan baru berdasarkan pengalaman dalam beraktifitas secara nyata (Ali \& Rusli, 2016).

Berdasarkan permasalahan di atas maka dilakukan penelitian tentang pengaruh penggunaan model PjBL terhadap keterampilan berpikir kreatif mahasiswa pada matakuliah fisika terapan.

\section{METODE PENELITIAN}

Penelitian ini dilakukan di FKIP Program Studi Pendidikan Fisika Universitas Islam Madura. Jenis penelitian ini adalah eksperimen semu. Tujuan penelitian eksperimen semu adalah untuk memperoleh informasi yang merupakan perkiraan bagi informasi yang dapat diperoleh dengan eksperimen yang sebenamya dalam keadaan yang tidak rnemungkinkan untuk mengontrol dan/atau memanipulasi semua variabel yang relevan (Sugiyono, 2013). Desain penelitian menggunakan Rancangan non equivalent Pretes-Postes design. Sampel dari penelitian ini adalah kelas F-A sebagai kelas eksperimen dan F-B sebagai kelas kontrol. Penarikan sampel pada penelitian ini ditentukan dengan menggunakan tekhnik purposive sampling atau penentuan sampel dengan pertimbangan tertentu. Satu kelas diberikan model project based learning (kelas eksperimen) dan kelas lainnya menggunakan model pembelajaran inkuiri (kelas kontrol).

Instrumen yang digunakan dalam penelitian ini adalah instrumen tes keterampilan berpikir kreatif. Tes yang digunakan berupa tes essay sebanyak 6 item soal yang sudah dibakukan melalui validitas ahli. Instrumen tes keterampilan berpikir kreatif dikembangkan dalam bentuk soal uraian dengan indikator berpikir lancar, berpikir luwes, berpikir orisinil dan berpikir elaborative (Lestari, Sarwi, \& Sumarti, 2018). Analisis data kuantitatif dimulai dengant uji prasyarat, yang terdiri dari uji normalitas data menggunakan uji Kolmogorov Smirnov pada taraf signifikansi $a=0,05$ dan uji homogenitas data menggunakan Levene's pada taraf signifikansi $a=0,05$. Data dianalisis menggunakan program SPSS for windows 22,00 . Setelah uji prasyarat terpenuhi selanjutnya dilakukan pengujian hipotesis penelitian data keterampilan berpikir kreatif dianalisis menggunakan teknik analisis kovariat (anacova) pada taraf signifikansi $a=0,05$.

Analisis data keterampilan berpikir kreatif dilakukan berdasarkan nilai yang diperoleh siswa saat pretest dan posttest. Nilai keterampilan berpikir kreatif tersebut dianalisis secara deskriptif kuantitatif dengan menggunakan rumus : 


$$
\% \mathrm{KBK}=\frac{\text { skor yang diperoleh }}{\text { skor maksimal }} \times 100 \%
$$

Tabel 1. Kriteria Keterampilan Berpikir Kreatif

\begin{tabular}{cc}
\hline Interval & Kategori \\
\hline $80 \%-100 \%$ & Sangat kretaif \\
\hline $66 \%-79 \%$ & Kreatif \\
\hline $56 \%-65 \%$ & Cukup kreatif \\
\hline $40 \%-55 \%$ & Kurang kreatif \\
\hline $30 \%-39 \%$ & Tidak kreatif \\
\hline
\end{tabular}

\section{HASIL DAN PEMBAHASAN}

Pada gambar grafik dibawah ini, data deskriptif keterampilan berpikir kreatif mahasiswa pada kedua kelas eksperimen dan kelas kontrol dapat dilihat bahwa keterampilan berpikir kreatif mahasiswa dari hasil posttest rata-rata berada pada katagori kreatif. Persentase hasil pos tes dari keterampilan berpikir kreatif mahasiswa di kelas eksperimen pada tingkat berpikir lancar adalah $82.58 \%$ (sangat kreatif) dan kelas kontrol $77.65 \%$ (kreatif). Hal ini menyatakan bahwa pada inidikator berpikir lancar terdapat pengaruh yang signifikan penggunaan model project based learning terhadap keteramplan berpikir lancar mahasiswa. Pada indikator berpikir luwes kelas eksperimen dengan model project based learning mendapatkan persentase $74.62 \%$ (kreatif) sedangkan kelas kontrol dengan model inkuiri mendapatkan $72.35 \%$ (kreatif). Hal ini menyatakan bahwa pada inidikator berpikir luwes tidak terdapat pengaruh yang signifikan terhadap keteramplan berpikir luwes antara kedua kelas yang menggunakan model project based learning dan model inkuiri karena kedua model tersebut baik dalam menggali keterampilan berpikir luwes mahasiswa.

Indikator berpikir orisinil pada kelas eksperimen adalah 64.20\% (cukup kreatif) sedang kelas kontrol 63.64\% (cukup kreatif). Dilihat dari hasil yang ada, maka kedua kelas yang menggunkan model project based learning dan model inkuiri tidak terdapat pengaruh yang signifikan sehingga kedua model tersebut masing-masing baik dalam meningkatkan keterampilan berpikir orisinil mahasiswa.Indikator berpikir elaborasi pada kelas eksperimen adalah 76.14 (kreatif) \% dan kelas kontrol adalah 69.89\% (kreatif). Pada indikator ini terdapat pengaruh yang signifikan dari segi kuantitatif tetapi dari segi kualitatif tidak terdapat pengaruh yang signifikan karena kategori nilai yang diperoleh kedua kelas masih dalam kategori kreatif. Secara kuantitatif keterampilan berpikir lancar yang paling tampak dari semua indikator yang ada Sehingga peningkatan kelancaran (fluently) harus termasuk dalam kategori kreatif atau sangat kreatif (Chiang \& Lee, 2016).

Persentase paling rendah diperoleh pada aspek berpikir kreatif secara orisinil, hal ini dikarenakan mahasiswa belum biasa terlatih dalam menghadapi soal yang bersifat gagasan dan penemuan baru. Mahasiswa cenderung menyelesaikan soal latihan dengan beberapa langkah penyelesaian. Mahasiswa tidak pernah ditantang untuk menyelesaikan soal latihan dengan cara lain atau dengan cara mereka sendiri yang bersifat logis dan penalaran. Hal ini mengakibatkan kemampuan mahasiswa dalam memberikan gagasan baru dan jarang diberikan kebanyakan 
orang (berpikir orisinil) memperoleh prosentase paling rendah dibandingkan aspek keterampilan berpikir kreatif lainnya.

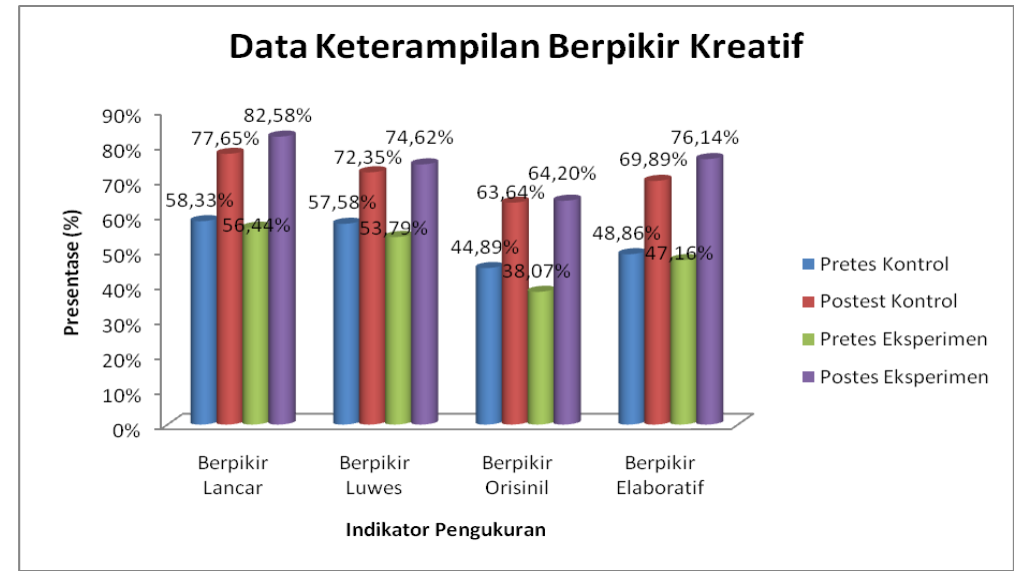

Gambar 1. Grafik keterampilan berpikir kreatif

Hubungan keterampilan berpikir kreatif mahasiswa dengan tahap-tahap model pembelajaran yang digunakan baik di kelas eksperimen maupun kelas kontrol. Tahap-tahap model project based learning yang di gunakan di kelas eksperimen ada 6 fase yaitu (1) penentuan pertanyaan mendasar, (2) mendesain perencanaan proyek, (3) menyusun jadwal, (4) memonitor peserta didik dan kemajuan proyek, (5) menguji hasil dan (6) mengevaluasi. Keenam fase model project based learning ini mendukung untuk meningkatkan indikator-indikator keterampilan berpikir kreatif yaitu (1) berpikir lancar, (2) berpikir luwes, (3) berpikir original, dan (4) elaborasi.

\section{Deskripsi Data Hasil Uji Normalitas}

Hasil uji normalitas data kelas eksperimen disajikan pada Tabel 2, sedangkan data kelas kontrol pada Tabel 3.

Tabel 2 Hasil Uji Normalitas Data Kelas Eksperimen

\begin{tabular}{llr}
\hline & & $\begin{array}{c}\text { Posttest keterampilan } \\
\text { berpikir kreatif }\end{array}$ \\
\hline N & Mean & 22 \\
Normal Parametersb,c & Std. Deviation & 75.2273 \\
& Absolute & 6.11930 \\
Most Extreme Differences & Positive & .145 \\
& Negative & .089 \\
Test Statistic & & -.145 \\
Asymp. Sig. (2-tailed) & .145 \\
\hline a. Kelas = Eksperimen & & $.200 \mathrm{~d}, \mathrm{e}$ \\
b. Test distribution is Normal. & \\
c. Calculated from data. & \\
d. Lilliefors Significance Correction. & \\
e. This is a lower bound of the true significance. &
\end{tabular}


Tabel 3 Hasil Uji Normalitas Data Kelas Kontrol

\begin{tabular}{llr}
\hline & & $\begin{array}{c}\text { Posttest keterampilan } \\
\text { berpikir kreatif }\end{array}$ \\
\hline N & Mean & 22 \\
Normal Parametersb,c & Std. Deviation & 71.7045 \\
& Absolute & 6.14247 \\
Most Extreme Differences & Positive & .142 \\
& Negative & .117 \\
Test Statistic & & -.142 \\
Asymp. Sig. (2-tailed) & .142 \\
\hline a. Kelas = Kontrol & & $.200 \mathrm{~d}, \mathrm{e}$ \\
b. Test distribution is Normal. & \\
c. Calculated from data. & \\
d. Lilliefors Significance Correction. & \\
e. This is a lower bound of the true significance. &
\end{tabular}

Uji normalitas dilakukan untuk mengetahui data berasal dari populasi yang berdistribusi normal atau tidak. Uji statistik yang akan digunakan adalah uji Kolmogrov-Smirnov dengan mengambil taraf signifikansi a sebesar 0.05 dengan hipotesis statistik sebagai berikut:

HO : Data keterampilan berpikir kreatif mahasiswa berasal dari populasi yang berdistribusi normal

H1 : Data keterampilan berpikir kreatif mahasiswa berasal dari populasi yang tidak berdistribusi normal

Kriteria pengujiannya adalah: $\mathrm{HO}$ diterima jika nilai signifikansi $>0.05$ dan $\mathrm{HO}$ ditolak jika nilai signifikansi $<0.05$. Hasil uji normalitas data kelas eksperimen dan kelas kontrol sesuai Tabel 2 dan Tabel 3 secara berturut-turut memiliki $p$-value sebesar 0,200 dan 0,200. Data pretest dan postest memiliki $p$-value $>\alpha(\alpha=0,05)$. Dengan demikian, menurut uji Kolmogorov Smirnov, dapat disimpulkan data kelas eksperimen dan kelas kontrol terdistribusi normal yang mengkonfirmasi bahwa $\mathrm{HO}$ diterima sehingga dapat dilakukan analisis lebih lanjut.

\section{Deskripsi Data Hasil Uji Homogenitas}

Uji homogenitas dilakukan untuk mengetahui varians data homogen atau tidak. Uji statistik yang akan digunakan adalah Uji Levene dengan mengambil taraf signifikansi a sebesar 0.05. Hipotesis statistik sebagai berikut:

$\mathrm{HO}$ : Kedua data memiliki varians yang homogen,

$\mathrm{H} 1$ : Kedua data memiliki varians yang tidak homogen.

Kriteria pengujiannya adalah: $\mathrm{HO}$ diterima jika nilai signifikansi $>0.05$ dan HO ditolak jika nilai signifikansi $<0.05$. Hasil uji homogenitas data Pretest dan Postest pada kelas eksperimen sebagai berikut: 
Tabel 4 Hasil Uji Homogenitas

\begin{tabular}{ccccl}
\hline Variabel & F & df1 & df2 & Sig. \\
\hline Keterampilan berpikir kreatif & .108 & 1 & 42 & .744 \\
\hline
\end{tabular}

Berdasarkan tabel 4 diatas, Hasil uji homogenitas data keterampilan berpikir kreatif sesuai menunjukkan $p$-value sebesar $0,744>\alpha(\alpha=0,05)$. Dengan demikian, Berarti $\mathrm{HO}$ diterima dan dapat disimpulkan data keterampilan berpikir kreatif homogen.

\section{Deskripsi Data Hasil Uji Hipotesis}

Uji hipotesis dilakukan untuk mengetahui ada tidaknya pengaruh dari penerapan model pembelajaran berbasis proyek terhadap keterampilan berpikir kreatif mahasiswa, maka selanjutnya dapat dilakukan uji hipotesis dengan menggunakan uji statistik uji t, dengan ketentuan hipotesis sebagai berikut :

$\mathrm{HO}$ : Tidak ada pengaruh yang signifikan dari penggunaan model PjBL terhadap keterampilan berpikir kreatif mahasiswa.

$\mathrm{H} 1$ : Ada pengaruh yang signifikan dari penggunaan model PjBL terhadap keterampilan berpikir kreatif mahasiswa.

Hasil uji anakova pengaruh model pembelajaran terhadap siswa ditunjukkan pada Tabel 5:

Tabel 5 Hasil Uji Anakova Pengaruh Model Pembelajaran terhadap Keterampilan Berpikir Kreatif

\begin{tabular}{lrrrrr}
\hline \multicolumn{1}{c}{ Source } & $\begin{array}{c}\text { Type III Sum of } \\
\text { Squares }\end{array}$ & df & Mean Square & F & \multicolumn{1}{c}{ Sig. } \\
\hline Corrected Model & $263.628 \mathrm{a}$ & 2 & 131.814 & 3.723 & .033 \\
Intercept & 1553.633 & 1 & 1553.633 & 43.883 & .000 \\
Xkreatif & 127.123 & 1 & 127.123 & 3.591 & .065 \\
Kelas & 211.139 & 1 & 211.139 & 5.964 & .019 \\
Error & 1451.571 & 41 & 35.404 & & \\
Total & 239193.750 & 44 & & & \\
Corrected Total & 1715.199 & 43 & & & \\
\hline
\end{tabular}

a. R Squared $=.154$ (Adjusted R Squared $=.112)$

\section{KESIMPULAN}

Dari hasil analisis data dan pembahasan dapat disimpulkan bahwa terdapat pengaruh yang signifikan dari penggunakan model Project Based Learning (PjBL) terhadap keterampilan berfikir kritis mahasiswa pada matakuliah Fisika Terapan. $\mathrm{Hal}$ ini dapat ditunjukkan bahwa kelas Eksperimen memiliki pencapaian keterampilan berpikir kreatif yang secara signifikan lebih tinggi dari kelas kontrol.

\section{UCAPAN TERIMAKASIH}

Penelitian ini merupakan hibah penelitian dosen pemula yang didanai oleh anggaran DRPM direktorat riset dan pengabdian kepada masyarakat. Penulis mengucapkan banyak terimakasih kepada pihak-pihak yang terlibat khususnya KEMENRISTEKDIKTI. 


\section{DAFTAR PUSTAKA}

Ali, M. S., \& Rusli, M. A. (2016). Pengaruh model Project-Based Learning terhadap hasil belajar fisika dan kemampuan berpikir kritis peserta didik SMA Negeri 1 Tanete Riaja. Jurnal Sains dan Pendidikan Fisika, 12(1), 60-68.

Chiang, C. L., \& Lee, H. (2016). The Effect of Project-Based Learning on Learning Motivation and Problem-Solving Ability of Vocational High School Students. International Journal of Information and Education Technology, 6(9), 709712. doi:10.7763/IJIET.2016.V6.779

Jagantara, I. M. W., Adnyana, P. B., \& Widiyanti, N. L. P. M. (2014). Pengaruh model pembelajaran berbasis proyek (Project Based Learning) terhadap hasil belajar biologi ditinjau dari gaya belajar siswa SMA. Jurnal Pendidikan dan Pembelajaran IPA Indonesia, 4(1).

Lestari, T. P., Sarwi, S., \& Sumarti, S. S. (2018). STEM-based Project Based Learning model to increase science process and creative thinking skills of 5th grade. Journal of Primary Education, 7(1), 18-24.

Purwasih, R., Ambarita, A., \& Muncarno, M. (2017). Pengaruh Project Based Learning terhadap Hasil Belajar Tematik. Jurnal Pedagogi, 5(9).

Sugiyono. (2013). Metode Penelitian Pendidikan Pendekatan Kuantitatif, Kualtitatif dan $R \& D$. Bandung: Alfabeta.

Triani, W., Zulkarnain, Z., \& Utami, R. K. S. (2015). Pengaruh Model Pembelajaran Project Based Learning Terhadap Hasil Belajar Geografi. JPG (Jurnal Penelitian Geografi), 3(7).

Waluyo, P. (2014). Pengaruh Model Pembelajaran Project Based Learning terhadap Hasil Belajar Siswa pada Standar Kompetensi Mengoperasikan Pengendali PLC di SMK Negeri 1 Madiun. Jurnal Pendidikan Teknik Elektro, $3(3)$.

Yunianta, T., Rusilowati, A., \& Rochmad, R. (2012). Kemampuan berpikir kreatif siswa pada implementasi Project-Based Learning dengan Peer and Self Assessment. Unnes Journal of Mathematics Education Research, 1(2). 